\title{
PENINGKATAN KETERAMPILAN PROSES SISWA KELAS VII SMP NEGERI 202 JAKARTA MELALUI PENERAPAN PROBLEM BASED LEARNING DENGAN METODE EKSPERIMEN PADA MATERI KALOR
}

\author{
EVY ALDIYAH \\ SMP Negeri 202 Jakarta \\ Email : evycantiq202@gmail.com
}

\begin{abstract}
ABSTRAK
Berangkat dari permasalahan pembelajaran materi Kalor dimana masih ada siswa mengalami kesulitan untuk memahaminya serta kurangnya aktivitas belajar siswa, maka melalui penelitian tindakan kelas ini penulis mencoba mencari solusi dengan melakukan perubahan metode pembelajaran. Diharapkan terjadi peningkatan terhadap keaktifan siswa selama proses pembelajaran materi tersebut dan hasil belajar siswapun meningkat. Penerapan model pembelajaran Problem Best Learning dengan metode eksperimen dianggap sesuai dalam proses pembelajaran materi Kalor pada Kompetensi Dasar 3.4. Kalor dan Perpindahannya. Tujuan penelitian tindakan kelas ini adalah mendeskripsikan adanya peningkatan keterampilan proses siswa kelas VII SMP Negeri 202 Jakarta melalui penerapan model pembelajaran Problem Based Learning dengan metode eksperimen pada materi Kalor. Sampel penelitian ini adalah siswa kelas VII-A, pembelajaran dilakukan pada masa pembelajaran tatap muka terbatas dalam 2 siklus. Penerapan model pembelajaran Problem Based Learning dengan metode eksperimen pada materi Kalor dapat meningkatkan keterampilan proses siswa kelas VII-A, terlihat dari persentase hasil akhir kinerja kelompok. Dari 8 kelompok siswa, hanya 2 kelompok dengan persentase hasil kinerja 75\% dalam katagori baik, selebihnya ada 6 kelompok dalam katagori sangat baik dengan persentase 95\%. Selain itu, penerapan model pembelajaran Problem Based Learning dengan metode eksperimen pada materi Kalor juga dapat meningkatkan aktivitas belajar siswa kelas VII-A, terlihat dari peningkatan persentase aktivitas belajar yang cukup signifikan dari $62,50 \%$ pada siklus I menjadi $93,06 \%$ pada siklus II dengan katagori sangat baik. Selain meningkatkan keterampilan proses siswa dan aktivitas belajar siswa, penerapan model pembelajaran Problem Based Learning dengan metode eksperimen pada materi Kalor ini juga membuat siswa merasa senang belajar IPA sehingga meningkatkan motivasi belajar siswa.
\end{abstract}

Kata Kunci : Problem Based Learning, Metode Eksperimen, Keterampilan Siswa

\section{ABSTRACT}

Departing from the problem of learning the Heat material where there are still students having difficulty understanding it and the lack of student learning activities, then through this classroom action research the author tries to find a solution by changing the learning method. It is expected that there will be an increase in student activity during the learning process of the material and student learning outcomes will increase. The application of the Problem Best Learning learning model with the experimental method is considered appropriate in the process of learning the Heat material in Basic Competencies 3.4. Heat and Its Displacement. The purpose of this classroom action research is to describe an increase in the process skills of class VII students of SMP Negeri 202 Jakarta through the application of the Problem Based Learning learning model with the experimental method on the heat material. The sample of this study were students of class VII-A, learning was carried out during a limited face-to-face learning period in 2 cycles. The application of the Problem Based Learning learning model with the experimental method on heat material can improve the process skills of class VII-A students, as can be seen from the percentage of the final results of group performance. Of the 8 groups of students, only 2 groups with a percentage of performance results of $75 \%$ in the good category, the rest there are 6 groups in the very good category with a percentage of $95 \%$. In addition, the application of the Problem Based Learning learning model with the experimental method on 
heat material can also increase the learning activities of class VII-A students, it can be seen from the significant increase in the percentage of learning activities from $62.50 \%$ in the first cycle to $93.06 \%$ in the first cycle. II with very good category. In addition to improving students' process skills and student learning activities, the application of the Problem Based Learning learning model with the experimental method on the Heat material also makes students feel happy about learning science, thereby increasing student learning motivation.

Keywords: Problem Based Learning, Experimental Method, Student Skills

\section{PENDAHULUAN}

Von Glaserfeld mengemukakan bahwa salah satu faktor penentu prestasi dan hasil belajar sains adalah faktor kemampuan guru dalam menerapkannya, guru perlu memahami cara pikir siswa untuk dapat membantu memodifikasinya (Hikmawati, 2012). Berdasarkan pendapat tersebut maka dalam memandang pembelajaran sains guru tidak hanya menekankan pada hasil. Proses pemahaman konsep juga perlu penekanan melalui keterampilan, sehingga siswa memperoleh pemahaman mereka sendiri yang lebih mendalam tentang alam sekitar.

Pada pembelajaran IPA, pembelajaran penemuan melalui penyelidikan dapat dikembangkan bersamaan dengan mengembangkan dan meningkatkan aspek keterampilan proses IPA. Menurut Samatowa (2011) dalam Aldiyah (2021), pembelajaran yang mengedepankan hands-on atau belajar sambil melakukan, akan memberikan kesan yang lebih mudah diingat oleh siswa. Hal tersebut menjadi kunci utama proses pembelajaran dalam menghubungkan antara materi dengan keterampilan proses sains. Pembelajaran dengan menggunakan metode eksperimen, percobaan atau demonstrasi merupakan upaya dalam pengembangan dan peningkatan keterampilan proses siswa.

Menurut Eliyana (2020), keterampilan proses adalah suatu cara atau pendekatan mengajar yang membantu membelajarkan siswa, sehingga mudah memahami konsep melalui penyelidikan. Keterampilan proses juga merupakan pendekatan proses dalam pengajaran ilmu pengetahuan alam didasarkan atas pengamatan terhadap apa yang dilakukan oleh seorang ilmuwan (Rusman, 2013). Keterampilan proses sains siswa harus dikembangkan dan ditingkatkan agar berguna bagi siswa. Selain sebagai proses untuk membangun pengetahuan dalam pembelajaran juga dalam kehidupan sehari-hari, sebagai persiapan dan latihan dalam menghadapi kenyataan hidup di masyarakat. Menurut beberapa pakar pendekatan keterampilan proses ini merupakan pendekatan yang paling sesuai dengan pelaksanaanpembelajaran di sekolah, dalam rangka menghadapi pertumbuhan dan perkembangan ilmu pengetahuan dan teknologi yang semakin cepat (Hikmawati, 2012)

Dibutuhkan suatu pendekatan dan model pembelajaran yang sesuai dalam upaya mengatasi masalah-masalah tersebut. Agar terjadi interaksi antara guru dengan peserta didik maupun antar peserta didik pada saat proses pembelajaran. Salah satu model yang dapat digunakan untuk meningkatkan pemahaman peserta didik terhadap materi dan juga menuntut peserta didik untuk lebih aktif dalam proses pembelajaran yaitu model pembelajaran Problem Based Learning (PBL). Jadi Problem Based Learning merupakan salah satu metode pembelajaran yang mendukung pengembangan keterampilan proses siswa, dimana pada awal pembelajaran peserta didik diberi permasalahan terlebih dahulu selanjutnya masalah tersebut diinvestigasi dan dianalisis untuk dicari solusinya. Jadi, peran guru dalam pembelajaran adalah memberikan berbagai masalah, pertanyaan, dan memberikan fasilitas terhadap penyelidikan peserta didik.

Banyak hal yang mempengaruhi ketidaksuksesan dalam pembelajaran. Pemilihan metode pembelajaran yang kurang tepat dan tidak sesuai dengan materi yang disampaikan dapat menyebabkan siswa kurang dapat memahami materi dengan baik. Semua pendekatan dan metode pembelajaran memiliki kelebihan dan kelemahan. Namun, tidak semua pendekatan dan metode pembelajaran dapat digunakan untuk membelajarkan IPA. Pendekatan pembelajaran yang dapat dipilih dalam pembelajaran IPA harus mampu mengungkap karakteristik IPA itu sendiri. Pendekatan yang digunakan dalam penelitian adalah pendekatan inkuiri terbimbing melalui metode eksperimen dan demonstrasi. 
Metode Eksperimen adalah metode atau cara di mana guru dan murid bersama-sama mengerjakan sesuatu latihan atau percobaan untuk mengetahui pengaruh atau akibat dari sesuatu aksi (Wirdawati, 2017). Diungkapkan oleh Lunetta (1984) dalam Wirdawati (2017) bahwa masih banyak guru memberikan penekanan terlalu besar pada faktor ingatan, masih sangat kurang bimbingan pelaksanaan praktikum IPA, serta kurang menguasai penggunaan peralatan laboratorium. Metode Eksperimen menurut Dyasrini dkk (2013) adalah metode yang bertitik tolak dari suatu masalah yang hendak dipecahkan dan dalam prosedur kerjanya berpegang pada prinsip metode ilmiah. Menurut Abimanyu (2009), metode eksperimen merupakan cara penyajian pembelajaran dimana siswa melakukan percobaan untuk membuktikan sendiri suatu pertanyaan atau hipotesis yang dipelajari.

Ada beberapa kelebihan metode eksperimen menurut Wirdawati (2017) sebagaimana dikemukakan dalam tabel berikut :

Tabel 1. Kelebihan dan Kelemahan Metode Eksperimen

\begin{tabular}{l|l}
\hline \multicolumn{1}{c|}{ Kelebihan Metode Eksperimen } & \multicolumn{1}{c}{ Kelemahan Metode Eksperimen } \\
\hline 1.Meningkatkan kreatifitas siswa & 1.Peralatan eksperimen tidak memadai \\
\hline 2.Meningkatkan rasa percaya diri siswa & $\begin{array}{l}\text { 2.Siswa butuh waktu lama untuk } \\
\text { mengerjakan percobaan }\end{array}$ \\
\hline 3.Mengembangkan sikap ilmiah & $\begin{array}{l}\text { 3.Ada percobaan tertentu yang tidak dapat } \\
\text { langsung diketahui hasilnya }\end{array}$ \\
\hline $\begin{array}{l}\text { 4.Mengembangkan sikap untuk } \\
\text { melakukan eksplorasi }\end{array}$ & 4.Bila gagal harus mencoba lagi dari awal \\
\hline
\end{tabular}

Metode ini lebih sesuai untuk dilakukan dalam bidang-bidang ilmu dan teknologi, termasuk ilmu pengetahuan alam. Pembelajaran dengan metode eksperimen umumnya digunakan untuk pembelajaran materi yang menggunakan alat bantu atau media eksperimen. Langkah-langkah yang dilakukan pada pembelajaran dengan metode eksperimen adalah diawali dengan informasi kompetensi kepada siswa, lalu guru menyajikan gambaran umum materi bahan ajar kepada siswa, selanjutnya membagi tugas pembahasan materi untuk tiap kelompok. Kelompok siswa diberi kesempatan melakukan eksperimennya dan melakukan diskusi kelompok, selanjutnya melakukan diskusi kelas dan saling memberikan tanggapan. Diakhir kegiatan siswa membuat kesimpulan, melakukan refleksi dan evaluasi dibimbing oleh guru.

Dari pemantauan pembelajaran materi Kalor pada kelas VII semester Ganjil ditemukan beberapa kelemahan dalam kegiatan belajar mengajar. Kelemahan tersebut antara lain siswa kurang terampil dan cekatan dalam melakukan pengamatan,siswa kurang aktif dalam mengikuti kegiatan pembelajaran, siswa juga tampak bosan dan menjadi sibuk sendiri. Dalam masalah keterampilan proses masih banyak siswa yang kurang terampil dalam bertanya, mendeskripsikan hasil pengamatan dan mengomunikasikan hasil.

Dalam pelaksanaan pembelajaran materi Kalor ternyata masih ada siswa yang mengalami kesulitan untuk memahaminya meskipun telah menggunakan beberapa media ajar. Hal itu tampak dari kurangnya aktifitas dan hasil belajar siswa pada pembelajaran. Nilai keterampilan sebagai pengamatan dalam aspek keterampilan proses hanya mencapai $53 \%$ dan belum mencapai target minimal aspek keterampilan yang telah ditetapkan yaitu $83 \%$. Pada saat diberikan soal uji kompetensi $31 \%$ nilai siswa masih di bawah KKM. Sementara itu besar harapan guru agar semua peserta didik terlibat aktif dan termotivasi dalam mengikuti pelajaran yang diberikan dengan harapan agar hasil belajar menjadi lebih baik, terutama meningkatnya keterampilan proses.

Tujuan penelitian tindakan kelas ini adalah untuk mendeskripsikan adanya peningkatan keterampilan proses siswa kelas VII SMP Negeri 202 Jakarta melalui penerapan model pembelajaran Problem Based Learning dengan metode eksperimen pada materi Kalor. 


\section{METODE PENELITIAN}

Penelitian Tindakan Kelas menurut Rahman (2018), adalah penelitian yang dilakukan oleh guru di kelas di tempat dia mengajar, dengan penekanan pada penyempurnaan atau peningkatan proses dan praktik pembelajaran. Penelitian yang dilakukan ini bertempat di SMP Negeri 202 Jakarta, Jalan Buluh Perindu IV/1 Pondok Bambu Jakarta Timur. Subyek penelitian adalah peserta didik kelas VII-A SMP Negeri 202 Jakarta Tahun Pelajaran 2021/2022. Berjumlah 36 siswa yang terdiri dari 16 siswa laki-laki dan 20 siswa perempuan. Kegiatan penelitian berlangsung di kelas, memanfaatkan benda-benda yang ada di lingkungan sekitar. Penelitian ini dilakukan pada masa Pembelajaran Tatap Muka Terbatas. Waktu pelaksanaan penelitian ini dimulai pada minggu keempat bulan September 2021 hingga minggu terakhir bulan Desember 2021.

Desain penelitian tindakan kelas ini mengambil Model Kemmis dan Mc Taggart. Pelaksanaan kegiatan pembelajaran dilaksanakan dengan menggunakan dua siklus dimana setiap siklusnya dilaksanakan dua kali pertemuan. Siklus I dilaksanakan pada minggu pertama bulan Oktober hingga minggu keempat bulan Oktober 2021. Dilanjutkan dengan siklus II pada minggu pertama bulan November hingga minggu keempat bulan November 2021. Tahapan kegiatan yang dilakukan dalam setiap siklus adalah Perencanaan Tindakan (Planning), Pelaksanaan Tindakan (Acting), Observasi dan Evaluasi (Observing), Refleksi (Reflecting).

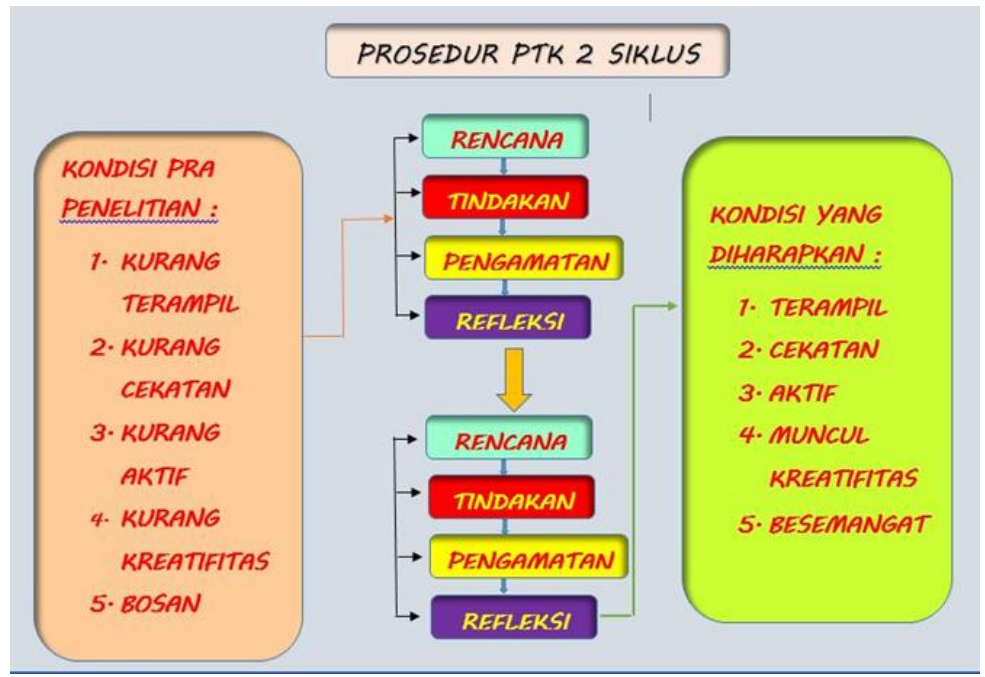

Gambar 1. Prosedur PTK 2 siklus

Jenis data yang diperoleh adalah data kualitatif dan data kuantitatif. Data kuantitatif berupa penilaian terhadap aspek keterampilan proses, selanjutnya data kualitatif tersebut dikonversi menjadi data kuantitatif. Cara pengambilan data menggunakan rubrik yang dilengkapi pedoman penskoran. Ada penilaian proses yang diambil selama kegiatan belajar da nada penilaian produk yang berupa hasil laporan individu dan kelompok.

Adapun teknik pengumpulan data berupa 1) Dokumentasi foto dan video yang diambil selama kegiatan berlangsung, 2) Observasi, berupa catatan pengamatan selama kegiatan berlangsung, 3) Postest, yang dilakukan pada akhir kegiatan pembelajaran. Semua data yang didapat akan direkap dan dianalisa untuk mendapatkan hasil nilai keterampilan proses dan ketuntasan belajar.

\section{HASIL DAN PEMBAHASAN \\ Deskripsi siklus I}

Kegiatan perencanaan ini dilakukan setelah melakukan pra penelitian. Dalam hal ini peneliti menjelaskan kepada observer tentang kegiatan pembelajaran yang akan dilakukan, yaitu dengan menerapkan model pembelajaran PBL dengan metode eksperimen dan menentukan hal-hal apa saja yang akan diobservasi. Selanjutnya peneliti menyusun Rencana 
Pelaksanaan Pembelajaran yang disesuaikan dengan masa PTMT, kegiatan belajar menggunakan model PBL dengan metode eksperimen diskenariokan dalam RPP PTK. Peneliti juga menyiapkan hal-hal berikut yaitu Lembar Observasi untuk mencatat aktivitas siswa dan guru selama pembelajaran berlangsung, menyiapkan Lembar Kerja Peserta Didik untuk setiap kegiatan pada tiap pertemuan, membuat pedoman penskoran penilaian proses aspek keterampilan, serta menyusun tes hasil belajar pada setiapakhir kegiatan dalam setiap pertemuan yang berupa soal PG. Selain itu guru juga menyiapkan lembar angket tanggapan siswa.

Kegiatan pembelajaran dilaksanakan di dalam ruang kelas tidak di dalam laboratorium IPA, karena situasi dan kondisi sekolah yang baru direnovasi dimana laboratorium IPA belum dalam keadaan rapi meskipun fasilitasnya lengkap. Kegiatan pembelajaran dilakukan sesuai dengan aturan prokes yang berlaku pada masa Pertemuan Tatap Muka Terbatas (PTMT), dimana PTMT dimulai pada awal bulan Oktober 2021. Satu pertemuan dalam 1 siklus dilakukan dua kali seminggu, sesuai dengan pembagian kelas Ganjil dan kelas Genap. Untuk lebih jelasnya bagaimana kegiatan pelaksanaan tindakan dilakukan dapat dilihat pada tabel berikut.

Tabel 2. Kegiatan PTK Dalam Masa Pembelajaran Tatap Muka Terbatas

\begin{tabular}{|c|c|c|c|c|}
\hline \multirow{2}{*}{$\begin{array}{c}\text { Kegiatan } \\
\text { Pembelajara } \\
\text { n Materi } \\
\text { Kalor }\end{array}$} & \multicolumn{2}{|c|}{ Siklus I } & \multicolumn{2}{|c|}{ Siklus II } \\
\hline & Pertemuan 1 & Pertemuan 2 & Pertemuan 1 & Pertemuan 2 \\
\hline $\begin{array}{l}\text { Untuk } \\
\text { kelas Ganjil }\end{array}$ & $\begin{array}{l}\text { Senin, } 4 \text { Oktober } \\
2021\end{array}$ & $\begin{array}{l}\text { Senin, } 18 \\
\text { Oktober } 2021\end{array}$ & $\begin{array}{l}\text { Senin, } 1 \\
\text { November } 2021\end{array}$ & $\begin{array}{l}\text { Senin, } 15 \\
\text { November } 2021\end{array}$ \\
\hline $\begin{array}{l}\text { Untuk } \\
\text { kelas Genap }\end{array}$ & $\begin{array}{l}\text { Senin,110ktobe } \\
\text { r } 2021\end{array}$ & $\begin{array}{l}\text { Senin, } 25 \\
\text { Oktober 2021 }\end{array}$ & $\begin{array}{l}\text { Senin, } \\
\text { November } 2021\end{array}$ & $\begin{array}{l}\text { Senin, } 22 \\
\text { November } 2021\end{array}$ \\
\hline
\end{tabular}

Selama pelaksanaan tindakan, diadakan observasi yang dilakukan secara langsung terhadap aktivitas peserta didik, dengan berpedoman pada Lembar Observasi dan pada penilaian aspek keterampilan proses dalam bentuk rubrik. Observer melakukan pengamatan terhadap aktivitas siswa, demikian pula peneliti yang berperan sebagai guru pada saat kegiatan pembelajaran. Hal-hal yang diamati adalah aktivitas selama kegiatan pembelajaran, terkait sikap dan tingkah laku siswa yang menunjukkan motivasi siswa dengan menggunakan lembar observasi.

Pada pelaksanaan tindakan siklus I diperoleh hasil yang belum optimal untuk capaian aktivitas belajar siswa. Pada pertemuan 1 diperoleh capaian $55,57 \%$ dan pada pertemuan 2 diperoleh capaian $69,44 \%$. Rata-rata capaian aktivitas pada siklus I adalah $62,50 \%$, belum memenuhi persentase target minimal yaitu $83 \%$. Hasil seperti yang ditunjukkan pada tabel berikut:

Tabel 3. Persentase Hasil Capaian Pada Siklus I

\begin{tabular}{|c|c|c|}
\hline \multirow[t]{2}{*}{ Penilaian } & \multicolumn{2}{|c|}{$\begin{array}{c}\text { Hasil Capaian (dalam } \\
\text { persentase) }\end{array}$} \\
\hline & Pertemuan 1 & Pertemuan 2 \\
\hline Aktivitas belajar siswa & 55,57 & 69,44 \\
\hline Keterampilan proses dalam kerja & & \\
\hline kelompok : & 60 & 60 \\
\hline - Kelompok 1 & 60 & 60 \\
\hline - Kelompok 2 & 70 & 80 \\
\hline - Kelompok 3 & 60 & 60 \\
\hline - $\quad$ Kelompok 4 & 80 & 90 \\
\hline - Kelompok 5 & 60 & 70 \\
\hline - $\quad$ Kelompok 6 & 80 & 90 \\
\hline
\end{tabular}




\begin{tabular}{llcc} 
- & Kelompok 7 & 70 & 80 \\
- & Kelompok 8 & & \\
\hline
\end{tabular}

Refleksi dilakukan pada akhir siklus, dilakukan dengan melihat hasil capaian pengamatan aktivitas siswa pada siklus I. Dari hasil pengamatan terhadap aktivitas siswa pada kegiatan pembelajaran siklus I rerata capaian hanya $62,50 \%$. Hal ini ternyata belum memenuhi target minimal yaitu $85 \%$. Pada point pembagian tugas dalam kelompok, mengajukan pertanyaan, menjawab pertanyaan dan memberikan pendapat atau tanggapan, semua masih dalam katagori kurang. Pada kegiatan pembelajaran siswa masih tampak malu, segan dan tegang. Hal ini dapat dimaklumi karena terkait dengan protokol PTMT dan masih sulit melakukan adaptasi setelah sekian lama belajar di rumah..

Guru tetap terus memberikan arahan dan motivasi kepada para siswa. Perbaikan pelaksanaan tindakan difokuskan pada aktivitas siswa pada point pembagian tugas dalam kelompok, mengajukan pertanyaan, menjawab pertanyaan dan memberikan pendapat atau tanggapan. Hasil refleksi ini digunakan sebagai dasar untuk memperbaiki serta menyempurnakan perencanaan dan pelaksanaan tindakan pada siklus selanjutnya.

\section{Deskripsi siklus II}

Setelah memperoleh hasil capaian pada pelaksanaan tindakan pada siklus I dimana ratarata capaian aktivitas siswa adalah $62,50 \%$, masih cukup jauh dari persentase minimal yang ditargetkan yaitu $83 \%$. Maka pada perencanaan siklus II ini peneliti sebagai pengajar perlu mengubah strategi dalam kegiatan pembelajarannya. Diharapkan para siswa menjadi lebih termotivasi lagi dalam aktivitas belajar.

Pada siklus II ini dilaksanakan strategi baru sesuai perencanaan. Dimana sehari sebelum PTMT para siswa diminta untuk lebih dulu mempelajari materi lalu membuat dua buah pertanyaan terkait materi. Strategi yang direncanakan pada saat pelaksanaan tindakan adalah setelah pemberian materi oleh guru, kelompok siswa diberikan kesempatan untuk mengajukan pertanyaan untuk dilempar kepada kelompok lain. Selanjutnya kelompok lain menjawab pertanyaan tersebut. Semua kelompok mendapat kesempatan untuk bertanya dan menjawab pertanyaan. Dengan harapan terjadi peningkatan keterampilan bertanya, menjawab pertanyaan dan mengemukakan pendapat.

Observasi dilakukan selama kegiatan berlangsung sama halnya pada kegiatan siklus I. Dari hasil pengamatan terhadap aktivitas siswa pada kegiatan pembelajaran siklus II menunjukkan adanya peningkatan dari siklus I.. Tampak siswa sudah mulai terampil untuk mengajukan pertanyaan dan menjawab pertanyaan. Secara umum aktivitas sudah dalam katagori baik. Hasil seperti yang ditunjukkan pada tabel berikut :

Tabel 4. Persentase Hasil Capaian Pada Siklus II

\begin{tabular}{|c|c|c|}
\hline \multirow[t]{2}{*}{ Penilaian } & \multicolumn{2}{|c|}{$\begin{array}{c}\text { Hasil Capaian (dalam } \\
\text { persentase) }\end{array}$} \\
\hline & Pertemuan 1 & Pertemuan 2 \\
\hline Aktivitas belajar siswa & 88,89 & 97,22 \\
\hline Keterampilan proses dalam kerja & & \\
\hline kelompok : & 80 & 90 \\
\hline - Kelompok 1 & 80 & 100 \\
\hline - Kelompok 2 & 90 & 90 \\
\hline - Kelompok 3 & 80 & 90 \\
\hline - $\quad$ Kelompok 4 & 90 & 100 \\
\hline - $\quad$ Kelompok 5 & 80 & 100 \\
\hline - $\quad$ Kelompok 6 & 90 & 100 \\
\hline - $\quad$ Kelompok 7 & 90 & 100 \\
\hline - $\quad$ Kelompok 8 & & \\
\hline
\end{tabular}


Pada pelaksanaan tindakan siklus II diperoleh hasil yang hampir maksimal untuk capaian aktivitas belajar siswa. Pada pertemuan 1 diperoleh capaian 88,89\% dan pada pertemuan 2 diperoleh capaian 97,22\%. Rata-rata capaian aktivitas pada siklus II adalah $93,06 \%$, melampaui taget persentase minimal yaitu $83 \%$. Dalam hal ini keterampilan yang ingin dicapai dari tindakan yang diberikan sudah tercapai dengan sangat baik, demikian pula aktivitas dan keikutsertaan siswa dalam belajar sudah dalam katagori sangat baik pada siklus II ini.

Berdasarkan hasil pengamatan terhadap aktivitas aiswa pada siklus I dan siklus II pada tiap siklus, terlihat bahwa aktivitas belajar siswa mengalami peningkatan. Demikian pula keterampilan proses siswa dalam kerja kelompok mengalami peningkatan dalam katagori sangat baik. Aktivitas belajar siswa mengalami peningkatan 30,56\% dari rerata capaian pada siklus I sebanyak 62,50\% sehingga menjadi 93,06\% pada siklus II. Aktivitas bekerja dalam kelompok, berbagi tugas, melakukan diskusi dan presentasi, dan interaksi yang terjadi antar siswa dan antara siswa dengan guru sudah dalam katagori baik. Pada aktivitas mengajukan pertanyaan dan memberikan tanggapan yang argumentatif dalam katagori cukup baik.. Hal ini menjadi catatan guru ke depan untuk menyusun strategi baru dalam meningkatkan keterampilan siswa untuk bertanya dan memberikan tanggapan yang argumentatif.

Peningkatan persentase aktivitas belajar yang cukup signifikan dari 62,50\% pada siklus I menjadi $93,06 \%$ pada siklus II ini dengan katagori sangat baik. Menunjukkan bahwa penerapan model pembelajaran Problem Based Learning dengan metode eksperimen pada materi Kalor dapat meningkatkan keterampilan proses siswa kelas VII-A. Hal ini sesuai dengan apa yang dikemukakan oleh Wirdawati (2017) bahwa pembelajarn dengan metode eksperimen dapat meningkatkan aktivitas dan kreatifitas siswa serta menumbuhkan rasa percaya diri siswa. Dan didukung pula oleh penelitian dari Murni dkk (2013) menggunakan metode eksperimen dimana terjadi peningkatan aktivitas belajar siswa, tampak dari kenaikan persentase setiap siklusnya dari rata-rata skor 2,22 pada siklus I, menjadi 3,89 pada siklus II dengan kategori sangat baik.

Persentase yang rendah pada awal siklus itu disebabkan karena beberapa faktor, salah satunya PTMT. Dimana selama ini siswa melakukan pembelajaran di rumah secara total, tentu saja siswa masih harus beradaptasi dulu dengan lingkungan sekitar termasuk dengan guru dan teman-teman dalam satu kelas.

Untuk lebih jelasnya persentase peningkatan aktivitas siswa pada siklus I dan siklus II dapat dilihat pada diagram berikut :

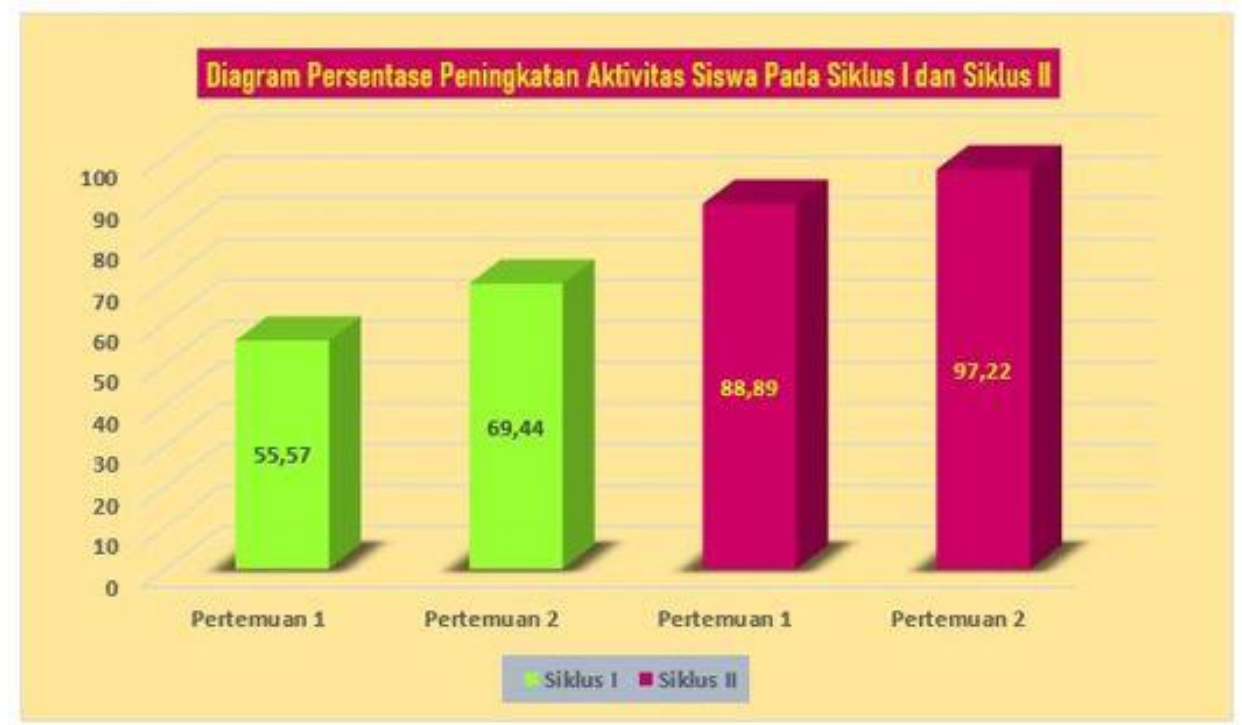

Gambar 2. Diagram Peresentase Peningkatan Aktivitas Siswa Pada siklus I dan siklus II 
Dalam melakukan kegiatan pembelajaran berupa penyelidikan atau eksperimen, siswa dibimbing secara terstruktur dalam suatu metode ilmiah sederhana. LKPD merupakan salah satu alat bantunya. Hasil kerja siswa dalam kelompok terkait keterampilan proses yang mereka kembangkan tergambar dalam penyusunan laporan penyelidikan dalam LKPD. Hal ini sejalan dengan pendapat Rizal dalam Wirdawati (2017) bahwa keterkaitan antara pembelajaran sains dengan metode eksperimen memberikan pengaruh nyata terhadap keterampilan proses siswa. Dalam proses belajar IPA harus diarahkan agar siswa mau mengerjakan langkah-langkah prosedur metode ilmiah hingga mereka memahaminya, sejalan dengan peningkatan keterampilan prosesnya.

Dalam penilaian hasil kerja kelompok siswa ada 5 aspek penilaian dalam bentuk rubrik. Aspek tersebut terkait dengan keterampilan proses dalam penerapan metode ilmiah. Kelima aspek yang dimaksud adalah 1) Melakukan kegiatan sesuai prosedur dengan baik, 2) Menyajikan dan mengkomunikasikan hasil kerja dengan baik dalam bentuk laporan, 3) Membuat data pengamatan dengan tepat, 4) Menjawab pertanyaan dengan tepat, 5) Membuat kesimpulan dengan tepat.

Hasil kerja siswa terhadap 5 aspek yang dinilai dapat dilihat pada tabel berikut ini :

Tabel 5. Peningkatan Keterampilan Proses Siswa Terhadap 5 Aspek Pada Siklus I dan Siklus II

\begin{tabular}{|c|c|c|c|c|c|c|}
\hline \multirow{2}{*}{$\begin{array}{c}\text { Kelompo } \\
\mathbf{k}\end{array}$} & \multicolumn{2}{|c|}{ Siklus I } & \multicolumn{2}{|c|}{ Siklus II } & \multirow{2}{*}{$\begin{array}{c}\text { Hasil } \\
\text { Akhir }\end{array}$} & \multirow{2}{*}{$\begin{array}{c}\text { Capaian } \\
(\%)\end{array}$} \\
\hline & $\begin{array}{c}\text { Sko } \\
\text { r }\end{array}$ & $\begin{array}{c}\text { Katagor } \\
\text { i }\end{array}$ & Skor & Katagori & & \\
\hline 1 & 6 & Kurang & 9 & Baik & 7,5 & 75 \\
\hline 2 & 6 & Kurang & 10 & Sangat Baik & 8,0 & 80 \\
\hline 3 & 8 & Cukup & 9 & Baik & 8,5 & 85 \\
\hline 4 & 6 & Kurang & 9 & Baik & 7,5 & 75 \\
\hline 5 & 9 & Baik & 10 & Sangat Baik & 9,5 & 95 \\
\hline 6 & 7 & Kurang & 10 & Sangat Baik & 8,5 & 85 \\
\hline 7 & 9 & Baik & 10 & Sangat Baik & 9,5 & 95 \\
\hline 8 & 8 & Cukup & 10 & Sangat Baik & 9,0 & 90 \\
\hline
\end{tabular}

Pada penilaian hasil kerja kelompok pada siklus I ada 4 kelompok yang dikatagorikan kurang dan 2 kelompok dalam katagori cukup, dan 2 kelompok lagi dalam katagori baik. Penilaian ini secara keseluruhan masih jauh dari harapan karena secara umum belum tampak keterampilan proses yang dikembangkan siswa. Ini terjadi karena salah satu faktor yaitu masa PTMT. Dimana selama ini siswa melakukan kegiatan belajar di rumah secara total, sehingga butuh waktu untuk beradaptasi dengan kegiatan pembelajaran di sekolah.

Pada siklus II mulai tampak peningkatan keterampilan proses siswa yang diharapkan. Dari 8 kelompok siswa, hanya 2 kelompok dalam katagori baik, selebihnya dalam katagori sangat baik. Ini menunjukkan adanya peningkatan keterampilan proses siswa sesuai dengan yang ditargetkan dalam penelitian tindakan ini. Dimana persentase capaian minimal $75 \%$ sebanyak 2 kelompok dan persentase capaian maksimal 95\% sebanyak 2 kelompok. berikut :

Peningkatan hasil kerja kelompok pada siklus I dan siklus II dapat dilihat pada diagram 


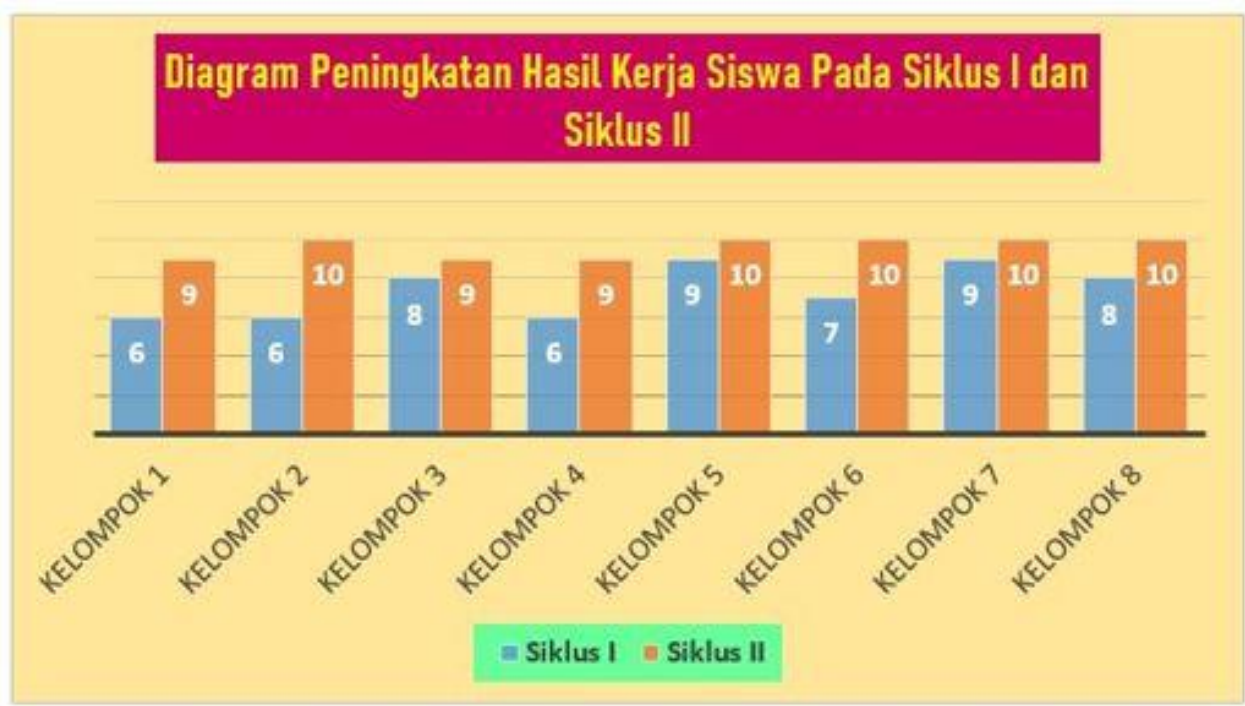

Gambar 3. Diagram Peningkatan Hasil Kerja Siswa Pada Siklus I dan Siklus II

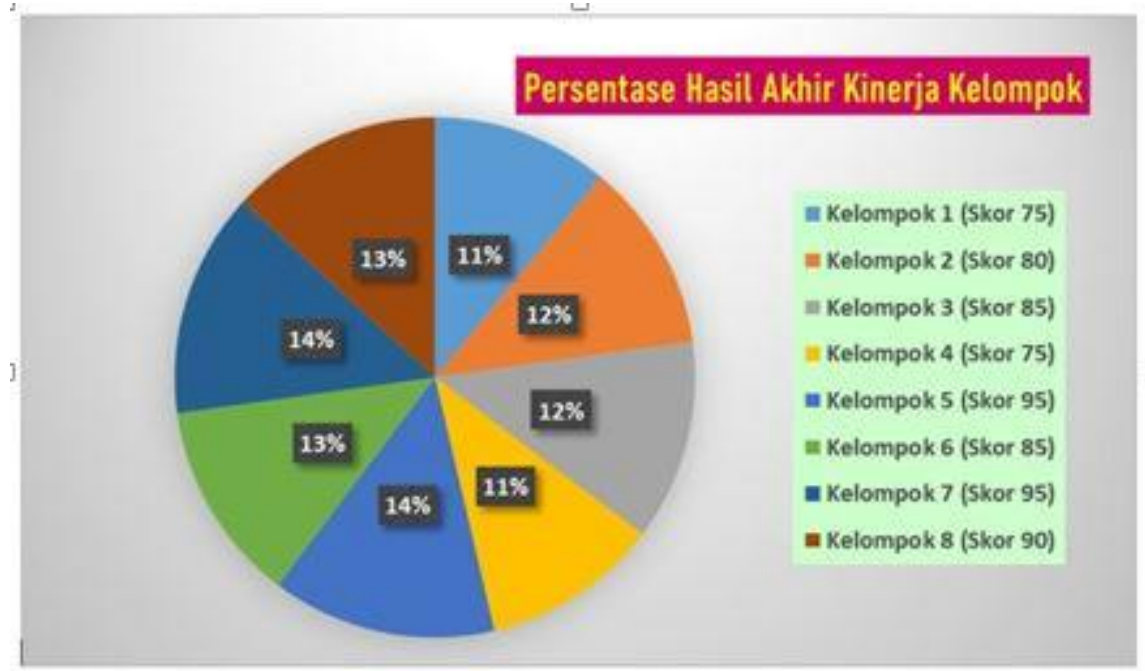

Gambar 4. Diagram Persentase Hasil Akhir Kinerja Kelompok

Aktivitas kinerja kelompok sudah terlaksana dengan baik, dimana masing-masing kelompok saling menghargai pendapat dalam berdiskusi dengan kelompoknya maupun menanggapi pertanyaan dari kelompok lain. Pelaksanaan jalannya diskusi pun berlangsung dengan tertib dan teratur. Semua kegiatan siswa dan guru selama pelaksanaan tindakan didokumentasikan dalam bentuk foto kegiatan belajar, lembar observasi dan lembar angket.

Pada setiap akhir siklus siswa diminta untuk mengisi angket tanggapan atau respon terhadap pembelajaran yang telah dilakukan. Berikut urutan hasil persentase respon siswa terhadap 10 elemen pernyataan pada akhir pelaksanaan tindakan.

Tabel 6. Urutan Hasil Respon Siswa Dengan Persentase Sangat Setuju

\begin{tabular}{clc}
\hline Urutan & \multicolumn{1}{c}{ Respon Terhadap Pernyataan } & $\begin{array}{c}\text { Persentase } \\
\text { Sangat } \\
\text { Setuju }\end{array}$ \\
\hline 1 & $\begin{array}{l}\text { 10.Saya senang belajar IPA materi Kalor dengan metode } \\
\text { eksperimen }\end{array}$ & 82,35 \\
\hline 2 & $\begin{array}{l}\text { 4. Pendekatan pembelajaran metode eksperimen pada } \\
\text { materi Kalor meningkatkan motivasi saya dalam belajar }\end{array}$ & 79,41 \\
\hline 3 & $\begin{array}{l}\text { 8 Pembelajaran materi Kalor dengan metode eksperimen } \\
\text { membuat saya mampu bekerja sama dan berhubungan baik } \\
\text { dengan sesama teman. }\end{array}$ & 79,41 \\
\hline
\end{tabular}




\begin{tabular}{clc}
\hline 4 & $\begin{array}{l}\text { 6 Pembelajaran materi Kalor dengan metode eksperimen } \\
\text { membuat saya menjadi lebih terampil dalam belajar IPA }\end{array}$ & 76,47 \\
\hline 5 & $\begin{array}{l}\text { 2. Materi Kalor yang disajikan dengan pendekatan metode } \\
\text { eksperimen membuat belajar menjadi menarik dan mudah } \\
\text { dipahami }\end{array}$ & 76,47 \\
\hline 6 & $\begin{array}{l}\text { 1. Pendekatan pembelajaran metode eksperimen } \\
\text { memudahkan saya dalam memahami materi yang diajarkan }\end{array}$ & 73,53 \\
\hline 7 & $\begin{array}{l}\text { 9.Pembelajaran materi Kalor dengan metode eksperimen } \\
\text { melatih saya untuk mampu mengkomunikasikan hasil kerja }\end{array}$ & 73,53 \\
\hline 8 & $\begin{array}{l}\text { 7 Pembelajaran materi Kalor dengan metode eksperimen } \\
\text { meningkatkan rasa percaya diri saya dalam belajar IPA. }\end{array}$ & 70,59 \\
\hline 9 & $\begin{array}{l}\text { 3. Pembelajaran materi Kalor dengan metode eksperimen } \\
\text { membuat saya lebih memahami kejadian-kejadian yang ada } \\
\text { di sekitar }\end{array}$ & 67,65 \\
\hline 10 & $\begin{array}{l}\text { 5. Pendekatan pembelajaran metode eksperimen melatih } \\
\text { saya untuk berpikir kritis, sistematis, serta memahami } \\
\text { konsep yang relevan di lingkungan. }\end{array}$ & 55,88 \\
\hline
\end{tabular}

Dari tabel 6 disimpulkan bahwa materi pembelajaran Kalor yang disampaikan menggunakan metode eksperimen menjadi menarik dan mudah dipahami siswa sehingga meningkatkan motivasi belajar siswa, menjadikan siswa lebih terampil dalam pembelajaran IPA, mampu bekerja sama dengan teman, dan mampu mengkomunikasikan hasil kerjanya. Terutama sekali adalah banyak siswa merasa senang belajar IPA materi Kalor dengan metode eksperimen. Hal ini sesuai dengan pendapat Schroenherr dalam Dyasrini dkk (2013) bahwa metode eksperimen adalah metode yang sesuai untuk pembelajaran sains dimana metode eksperimen mampu memberikan kondisi belajar yang menyenangkan bagi siswa karena dapat mengembangkan sendiri kemampuan berfikir dan kreatifitas mereka secara optimal.

Beberapa hal yang menjadi bahan refleksi bagi guru ke depan adalah bagaimana menyiapkan strategi baru untuk meningkatkan rasa percaya diri siswa dalam belajar IPA, dan melatih siswa berpikir kritis, sistematis dalam memahami konsep yang relevan dengan kejadian-kejadian yang ada disekitar, terkait dengan persentase respon siswa yang belum baik.

Berdasarkan hasil observasi dan hasil pembahasan diatas serta mengacu pada kriteria sukses yang telah ditetapkan, disimpulkan bahwa ada peningkatan keterampilan proses siswa kelas VII SMP Negeri 202 Jakarta melalui penerapan model Problem Based Learning dengan metode eksperimen pada materi Kalor. Maka pembelajaran materi Kalor dalam penelitian tindakan kelas ini dikatagorikan berhasil. Dengan demikan semua tujuan pembelajaran yang telah ditetapkan telah tercapai. Hal ini didukung oleh pendapat Setiawan \& Tulalessy (2021), bahwa indikator keberhasilan suatu penelitian tindakan dapat diukur antara lain dari : 1) Peningkatan keterampilan yang ingin dicapai dari tindakan yang diberikan, 2) Adanya keikutsertaan siswa dalam proses belajar, 3) Tercapainya tujuan pembelajaran, 4) Hasil tes yang berada di atas KKM (Setiawan \& Tulalessy, 2021).

\section{KESIMPULAN DAN SARAN}

Penerapan model pembelajaran Problem Based Learning dengan metode eksperimen pada materi Kalor dapat meningkatkan keterampilan proses siswa kelas VII-A, terlihat dari persentase hasil akhir kinerja kelompok. Dari 8 kelompok siswa, hanya 2 kelompok dengan persentase hasil kinerja 75\% dalam katagori baik, selebihnya ada 6 kelompok dalam katagori sangat baik dengan persentase 95\%. Selain itu, penerapan model pembelajaran Problem Based Learning dengan metode eksperimen pada materi Kalor juga dapat meningkatkan aktivitas belajar siswa kelas VII-A, terlihat dari peningkatan persentase aktivitas belajar yang cukup signifikan dari $62,50 \%$ pada siklus I menjadi $93,06 \%$ pada siklus II dengan katagori sangat baik. Selain meningkatkan keterampilan proses siswa dan aktivitas belajar siswa, penerapan 
model pembelajaran Problem Based Learning dengan metode eksperimen pada materi Kalor ini juga membuat siswa merasa senang belajar IPA sehingga meningkatkan motivasi belajar siswa.

Disarankan pemberian penjelasan tentang langkah-langkah kegiatan pembelajaran sangatdiutamakan sebelum melaksanakan pembelajaran agar siswa siap dalam proses pembelajarannya serta memudahkan dalam mengendalikan situasi dan kondisi kelas secara optimal sesuai dengan waktu yang telah ditetapkan. Dan diharapkan pula para pendidik berusaha selalu kreatif dalam menciptakan pembelajaran yang bermakna dengan menggunakan pendekatan metode belajar yang dapat meningkatkan dan mengembangkan keterampilan proses siswa.

\section{DAFTAR PUSTAKA}

Abimanyu, Soli dkk. (2009). Strategi Pembelajaran. Jakarta: Departemen Pendidikan Nasional Direktorat Jendral Pendidikan Tinggi.

Aldiyah, Evy (2021). Best Practice Mengembangkan Sikap Ilmiah dan Keterampilan Keterampilan Proses Peserta Didik Melalui Metode Ajar Problem Based Learning. SCIENCE : Jurnal Inovasi Pendidikan Matematika dan IPA Vol. 1 No. 1 Mei 2021. DOI : https://doi.org/10.51878/science.v1i1.190

Dyasrini, Rika., Sabri, Tahmid, \& Kresnad, Hery. (2013). Penerapan Metode Eksperimen Untuk Meningkatkan Aktivitas Belajar Peserta Didik Dalam Pembelajaran IPA di SD. http://media.neliti.com/media/publications/213767

Eliyana, Evi. (2020). Analisis Keterampilan Proses Sains Siswa Belajar IPA Materi Tumbuhan Hijau Pada Siswa Kelas V SDN 3 Panjerejo di Masa Pandemi Covid-19. Jurnal Ilmiah Pendidikan IPA Eduproxima Vol.2 No. 2 tahun 2020

Hikmawati. (2012). Penggunaan Pendekatan Keterampilan Proses Dalam Meningkatkan Hasil Belajar Pesawat Sederhana Siswa di Kelas V SDN 51 Lambari. Jurnal Publikasi Pendidikan Volume II No. 1

Rahman, Taufiqur. (2018). Aplikasi Model-Model Pembelajaran Dalam PTK. Semarang: CV Pilar Nusantara.

Rusman. (2013). Model-Model Pembelajaran Mengembangkan Profesionalisme Guru. Jakarta: PT. Raja Grafindo Persada.

Setiawan, Didang \& Tulalessy, Christina. (2021). Penelitian Tindakan Kelas : Apa, Mengapa, Bagaimana. Tangerang : CV. Makeda Multimedia Sarana.

Wirdawati. (2017). Penerapan Metode Eksperimen Pada Mata Pelajaran IPA Untuk Meningkatkan Hasil Belajar Siswa Kelas V di SDN 1 Rio Mukti. Jurnal Kreatif Tadulako Online Vol. 5 No. 5 ISSN 2345-614X16 